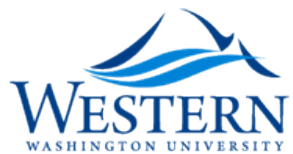

Western Washington University Western CEDAR

$11-1998$

\title{
Minority Representation under Cumulative and Limited Voting
}

Todd Donovan

Western Washington University, todd.donovan@wwu.edu

David Brockington

Shaun Bowler

Robert Brischetto

Follow this and additional works at: https://cedar.wwu.edu/politicalscience_facpubs

Part of the Political Science Commons

\section{Recommended Citation}

Donovan, Todd; Brockington, David; Bowler, Shaun; and Brischetto, Robert, "Minority Representation under Cumulative and Limited Voting" (1998). Political Science Faculty Publications. 11.

https://cedar.wwu.edu/politicalscience_facpubs/11 


\section{CAMBRIDGE UNIVERSITY PRESS}

\section{Southern Political Science Association}

Minority Representation under Cumulative and Limited Voting Author(s): David Brockington, Todd Donovan, Shaun Bowler and Robert Brischetto Source: The Journal of Politics, Vol. 60, No. 4 (Nov., 1998), pp. 1108-1125

Published by: Cambridge University Press on behalf of the Southern Political Science Association Stable URL: http://www.jstor.org/stable/2647733

Accessed: 23/10/2014 17:13

Your use of the JSTOR archive indicates your acceptance of the Terms \& Conditions of Use, available at http://www.jstor.org/page/info/about/policies/terms.jsp

JSTOR is a not-for-profit service that helps scholars, researchers, and students discover, use, and build upon a wide range of content in a trusted digital archive. We use information technology and tools to increase productivity and facilitate new forms of scholarship. For more information about JSTOR, please contact support@jstor.org. 


\title{
Minority Representation under Cumulative and Limited Voting
}

\author{
David Brockington \\ University of Washington \\ Todd Donovan \\ Western Washington University \\ Shaun Bowler \\ University of California, Riverside \\ Robert Brischetto \\ University of Texas, San Antonio
}

\begin{abstract}
We examine minority representation resulting from modified at-large elections (cumulative and limited voting) used in U.S. localities in the 1990s. Hypotheses about the relative proportionality of descriptive representation under various local election systems are presented and tested. We find that $\mathrm{CV} / \mathrm{LV}$ elections produced descriptive representation of African-Americans at levels similar to those in larger single-member district places, and at levels that exceed those from some small, southern SMD places. Results for Latino representation are more qualified. Our results offer encouragement for those interested in facilitating minority representation without using the acrimonious process of drawing districts on the basis of races.
\end{abstract}

$\mathbf{R}$ ecent decisions of the United States Supreme Court have directed increased attention at alternatives to districting for the purpose of minority representation (see Pildes and Donoghue 1995). In this paper we assess how modified at-large plans (limited and cumulative voting) might facilitate minority representation. We also examine how representation under these plans compares to that obtained with district and at-large elections.

In previous decades, court interpretations of the Voting Rights Act (VRA) broadened the ability of the U.S. Department of Justice and minority plaintiffs to challenge local election plans that might dilute minority vote strength (i.e., Thornburg v. Gingles 1986; Gomez v. Watsonville 1988). The plans most often

An earlier version of this paper was presented at the 1995 annual meeting of the American Political Science Association. Partial funding for the research was provided by the WWU Bureau for Faculty Research and by UC Riverside. Direct correspondence and requests for data used in this paper to Todd Donovan, Department of Political Science, WWU, Bellingham, WA 98225 (or donovan@nessie.cc.wwu.edu).

THE JOURNAL OF POLITICS, Vol. 60, No. 4, November 1998, Pp. 1108-25

(C) 1998 by the University of Texas Press, P.O. Box 7819, Austin, TX 78713-7819 
subject to challenge include councils elected under multimember, at-large systems. The standard remedy in these situations has been changing to single-member district (SMD) plans, with districts drawn to facilitate minority representation. Indeed, a substantial body of evidence demonstrates that racial and ethnic minorities are more likely to win seats proportionate to their share of the population in districted jurisdictions (Engstrom and McDonald 1981; Polinard, Wrinkle, and Longoria 1991; Welch 1990).

\section{Limits to Districting as a Remedy}

Districting on the basis of race, however, has come under increased scrutiny by the courts. The Shaw v. Reno decision (1993) criticized "bizarre"-shaped districts. Miller v. Johnson (1995) found a majority-minority congressional district unconstitutional and argued that districts should not be drawn based "on race in substantial disregard of customary and traditional districting practices." Shaw v. Hunt (1996) and Bush v. Vera (1996) found separate districting plans in violation of the Fourteenth Amendment's equal protection clause. When race is found to be the "predominant factor" in districting, the contemporary Court must apply the strict scrutiny test for the equal protection clause. This makes it extremely difficult for state and local governments to establish a compelling interest in adopting such districts.

Majority-minority districts have also come under criticism since they may "waste" votes (Lijphart 1994; Still 1984). Others suggest that districting can limit minority influence over policy (Guinier 1991, 1994; Sass and Mehay 1996) and prevent the formation of coalitions across racial lines (Swain 1993). There are practical problems as well. Edward Still (1991) notes that districts drawn with a $65 \%$ African-American population are perhaps the bare minimum required to facilitate African-American representation in some instances, although Brace et al. (1988) note that this minimum varies greatly by place.

\section{Cumulative and Limited Voting in the United States}

In response to the perceived limits of districting, cumulative voting (CV) and limited voting (LV) have been proposed as a means of increasing minority representation. A number of small- and medium-sized U.S. jurisdictions have adopted these plans (Amy 1993; Cole and Taebel 1992; Cole, Taebel, and Engstrom 1990; Still 1984, 1991). ${ }^{1}$ Both systems operate to elect multimember councils at-large and facilitate proportionality by changing how voters cast ballots.

Several jurisdictions in North Carolina, Alabama, and Texas adopted modified at-large systems (and to a lesser extent, places in New Mexico, South Dakota,

\footnotetext{
${ }^{1}$ There is only one jurisdiction in the United States with a population over 100,000 using a CV or LV system: Peoria, Illinois.
} 
and Illinois). Over 75 city councils, county councils, and school boards had adopted $\mathrm{CV}$ or $\mathrm{LV}$ at the time of this writing. ${ }^{2}$ These elections create relatively low thresholds of exclusion-the proportion of votes that a group needs to elect one candidate assuming all the group's voters support the candidate. In a CV election for a five-member council, for example, a minority candidate with $17 \%$ support could not be denied a seat. ${ }^{3}$

Under LV, voters are restricted to fewer votes than seats up for election. Candidates are elected by plurality, and candidates with the most votes win until seats are filled. In party systems, outcomes under LV are expected to be more proportionate the more limited the vote is relative to the number of seats at stake (for a description see Lakeman 1970, 80-88; Still 1984, 253-55). ${ }^{4}$ Cumulative voting modifies at-large plans by allowing voters to cast as many votes as seats being elected, with the additional option of clustering votes among any combination of candidates. The voter may typically distribute votes in any way she feels, including distributing them across fewer candidates than available seats. Candidates are elected by plurality, and candidates with the most votes win until seats are filled.

Variation in CV and LV plans in the United States is characterized by manipulation of two main factors: the rules regarding vote allocations, and the number of seats elected via CV or LV. Election rules determine the number of seats elected under $\mathrm{CV}$ or LV directly by reducing or enlarging the number of positions in a given jurisdiction, or indirectly through staggering the elections of those positions across time. Most applications of $\mathrm{CV}$ allow voters to distribute their votes as they choose, but at least one (Peoria, IL) constrains how votes are cast by providing only one space next to each candidate (then dividing five votes across the candidates marked).

Table 1 illustrates some important points about variation across modified atlarge election plans in U.S. places having 1,000 or more population. Clearly, there is no single CV or LV plan. Most places using CV elect their entire council at-large with $\mathrm{CV}$-although a small number of places mix $\mathrm{CV}$ with single-member districts (an example being Alamagordo, NM). Across all CV places, the average number of seats elected is only slightly lower than the average number of total seats (6.29 vs. 6.41$)$. Table 1 shows that these elections tend to occur in places having significant minority populations.

\footnotetext{
${ }^{2}$ Details about each jurisdiction's systems were identified with phone calls to local officials in each place. Communications with local officials and individuals involved with VRA litigation led to the identification of these communities. Several additional places are in the process of settling lawsuits that will result in the adoption of limited or cumulative voting.

${ }^{3}$ The threshold of exclusion for $\mathrm{CV}$ is equal to $1 /(1+$ [number of seats]).

${ }^{4}$ Lijphart $(1994,40)$ points out an extreme (hypothetical) case where three seats are contested and voters cast one vote. One candidate could win all but two votes while the second and third candidates receive one vote each. All would be elected if there is no legally defined minimum for election. The threshold of exclusion for $\mathrm{LV}$ is $\mathrm{V}(\mathrm{V}+\mathrm{n}$ ) where $\mathrm{V}=$ \# votes and $\mathrm{n}=$ \# of seats (Engstrom 1993, Still 1984).
} 
TABLE 1

\section{Cumulative and Limited Voting Arrangements in U.S. Communities}

Cumulative Voting ( $\mathrm{CV})$ :

Average number of total council seats per place

Average number elected at-large with $\mathrm{CV}$ per place

Average number elected $\mathrm{CV}$ per election

3.22

Average number minority seats per place ${ }^{a}$

Average percent minority voting age population ${ }^{\mathrm{a}}$

Number of cases (elections)

Limited Voting (LV):

Average number of total council seats per place

Average number elected at-large with LV per place

Average number elected LV per election

Average number minority seats per place ${ }^{a}$

Modal vote limit

Average percent minority voting age population ${ }^{\mathrm{a}}$

Number of cases (elections)

Note: Cases used for averages are based on individual elections.

${ }^{a}$ Figures for the largest minority group only.

Table 1 also demonstrates that many $\mathrm{CV}$ places do not elect all seats in a single election. In places outside of Texas, the entire board or council (typically five to seven members) is typically elected in a single election with CV. Yet in Texas, although the entire council is often elected by $\mathrm{CV}$, elections are staggered over time such that only two or three seats are up in a single contest. This causes the average number of seats elected via CV per place, per election cycle (3.22) to be substantially less than the average number of seats elected via CV per place (6.29).

In about one-third of places using LV, some seats are elected from singlemember districts with the remaining elected from multimember districts at-large. Conversely, about two-thirds of the places using LV elect all council seats from at-large, multimember districts. Few of these places elect all seats in the same election (most stagger elections). For this reason, many places limit voters to a single vote, typically cast in an election with three or four seats up (avg. $=4.00$ ). LV plans include further variation. At least one county utilizes place requirements (a candidate must reside in a specific multimember district elected via LV) and uses more than one multimember district. A small number of places allow voters to cast two to four votes, depending on how many seats are elected.

\section{Strategic Burdens under Limited and Cumulative Voting}

There are reasons to expect some deviations from proportionate descriptive representation in $\mathrm{CV}$ and $\mathrm{LV}$ places. CV and LV are often labeled as "semiproportionate" in classifications of electoral systems (Amy 1993; Lakeman 
1970). Much of the potential for these modified at-large plans to produce deviations from proportionality lie in the demands for strategic coordination (Cox 1997) that each system places at the mass and elite level. Under each system, a party or slating group must effectively maximize seats by controlling the candidate selection process such that they place an optimal number of candidates on the ballot. To optimize representation, the groups must also spread their supporters' votes accurately across those candidates they nominate (Still 1984, 254-55). Skill at this has been cited as an explanation for the seat bonuses $^{5}$ received by Japan's LDP under a form of limited voting (Cox and Niou 1994). If a group overnominates and lists too many candidates, it risks spreading the votes of supporters too thin, causing underrepresentation. If a group undernominates, it errs by possibly wasting votes that might have yielded another seat.

These strategic burdens can apply to both larger parties/groups and smaller parties/groups (Goldburg 1994; Silva 1964). However, Lijphart (1994) and others suggest that LV systems might be legitimately considered as PR since the strategic burdens are often likely to be greater for majorities than minorities. A minority group often need only nominate one candidate to insure some representation (or simply nominate as many candidates as votes allowed). Majority groups, in contrast, can have a greater risk of nomination errors (Lijphart 1994, 42; Taagepera and Shugart 1989; see also Cox 1991). Christensen and Johnson (1995) find Japan's SNTV system to be proportionate when compared to other PR systems if district magnitude (seats per district) is accounted for.

Control of nominations under CV might also be required for proportionate descriptive representation of minority groups, but CV further modifies at-large plans in a manner that can produce an additional strategic burden for groups. With CV, groups must coordinate their supporters' voting behavior to discourage voters from spreading their multiple votes in a manner that disperses electoral strength. In other words, voters must be informed about the optimal strategy of clustering votes among candidates. Plainly, CV can require strategic coordination at both the mass (vote distribution) and elite (nomination) levels, while LV might require less coordination if the vote is limited to one. As a result, Still $(1984,256)$ suggests that CV is likely to require more strategic voting than LV to achieve proportional results (on the possibility of strategic mistakes by minority voters in CV, see also Engstrom 1993).

Since CV allows voters more options when delivering their votes, the existence of such opportunities increases the probability that some minority voters will spread votes across multiple candidates, even if only one minority candidate is running. This, in turn, increases the chance that minority votes might go to nonminority candidates, potentially limiting the translation of minority vote

\footnotetext{
${ }^{5}$ The seat bonus is the proportion of seats a group receives in excess of its share of the vote.
} 
strength into seats. ${ }^{6}$ Furthermore, in CV or LV places where a group's population share is near the threshold of exclusion and voting is racially polarized, minority candidates can only be elected if their supporters turn out at a rate matching majority-group voters. All of this suggests that descriptive representation of minorities under $\mathrm{CV}$ might be somewhat less proportionate to population than that obtained under LV.

There are reasons to expect that each plan could produce less proportionate descriptive representation than SMD systems. With SMD plans, if cartographers have the ability to tailor boundaries to create heavily minority districts, and they create a number of minority districts in proportion to overall minority vote share in a jurisdiction, then proportionate descriptive representation can be expected. Compared to $\mathrm{CV} / \mathrm{LV}$, once homogeneous majority-minority districts are created, limited strategic behavior is required of elites (e.g., mobilization of minority voters in numbers approaching majority-group turnout and controlling nominations), and little strategic electoral behavior is required of voters (e.g., vote dispersion) to produce proportionate descriptive representation. ${ }^{7}$ In other words, districting can institutionalize some of the strategic actions needed to facilitate minority representation, and could possibly produce greater minority representation than $\mathrm{CV} / \mathrm{LV}$ systems.

\section{Hypotheses: Outcomes Under Modified At-Large Voting}

The discussion above suggests several testable propositions about how the seats-population relationship in modified at-large elections compares to those obtained under districting, to unmodified at-large (AL) plans, and how LV and $\mathrm{CV}$ results compare to each other.

First, we expect that modified at-large systems should produce more proportionate representation of minorities than that resulting from the traditional at-large method. Assuming that a group votes roughly as a block, any group winning a plurality is likely to sweep all seats in an unmodified at-large election (Lakeman 1970). Although nearly every electoral system has bias in favor of the group gaining the largest vote share in an election, the bias is greatest under American-style at-large, plurality systems (Johnson 1979). Conversely, both LV and CV have lower minimum thresholds than at-large elections. Cox (1991) illustrates that outcomes under forms of limited voting in party systems can even be equivalent to d'Hondt PR under certain obtainable conditions.

\footnotetext{
${ }^{6}$ Surveys from a city using CV illustrated that $36 \%$ of Latino voters used the option to cast at least one of their votes for a non-Latino candidate (Cole, Taebel, and Engstrom 1990; Cole and Taebel 1992).

${ }^{7}$ Optimal districting arrangements are a possibility where minority groups are highly segregated spatially. Since African-American housing is historically more segregated from whites than Latino housing (Massey and Denton 1987), districting might produce more-proportionate representation of African-Americans than of Latinos (Taebel 1978; see also Vedlitz and Johnson 1982).
} 
Second, given strategic demands and the "semiproportionate" nature of $\mathrm{CV} / \mathrm{LV}$, we expect that modified at-large local elections might produce lessproportionate descriptive representation of minorities than SMD elections. ${ }^{8}$ Modified at-large plans can facilitate minority representation by lowering the threshold of votes required for a minority candidate to win office, but groups must be fairly well organized politically to take advantage of these systems. SMD plans might facilitate minority representation with less coordination requirements for elites and voters.

Third, limited voting might be expected to produce more-proportionate outcomes than cumulative voting. This hypothesis is based on the assumption that the latter system can require an additional element of strategic behavior (coordination of vote dispersion) from voters and elites.

\section{Data and Framework for Analysis}

Cases for our tests are drawn from U.S. cities, counties, and school districts that adopted CV or LV in response to actual or anticipated VRA lawsuits. Since we are interested in estimating how electoral systems are related to representation of minority groups relative to their share of the local population, we limited our analysis to jurisdictions for which 1990 census population data are available. Initial information on local election systems and election results were obtained in the spring of 1995 via telephone interviews with city clerks and county election officials, with additional data acquired in subsequent interviews in 1996 and 1997. Nearly all the places we identified are located in three states: Texas, Alabama, and North Carolina. South Dakota, New Mexico, and Illinois each also have a single jurisdiction that used CV. We limit our analysis to places from these six states where the predominant minority made up less than $50 \%$ of the voting population.

We treat individual elections as cases. This allows us greater comparability in our analysis, largely because this diffuses the problem created by those jurisdictions that stagger elections. We include the two most recent elections from each jurisdiction in the analysis, or the most recent if the jurisdiction had only one CV or LV contest as of spring 1997. This allows us to capture variation in elections across places and within places, since most of these communities alternate the number of seats contested in consecutive elections. Data from nearly all these places involve elections contested between 1994 and 1997, although the second most recent elections in three places were held between 1990 and 1992.

The dependent variable is the percentage CV or LV seats won by minority candidates in each election. Our models thus isolate the seats-population rela-

\footnotetext{
${ }^{8}$ This logic does not suggest that any (national) electoral system using winner-take-all, singlemember districts would ever produce more proportionate outcomes than a multimember LV/SNTV or CV system. It is important to note that the difference in proportionality we expect is not so much a function of single-member districts per se, but of the apportionment of racial and ethnic groups into particular districts.
} 
tionship unique to modified at-large elections, and eliminate from the analysis those seats elected in these communities by other methods. ${ }^{9}$ Communities included in the seats-population analysis were limited to places with a population of more than 1,000, the minimum for racial information to be included in census data. Most communities are rather small, with a median population of 3,167 and a mean of 10,311 . The resulting sample used to assess the seatspopulation relationship includes a total of 62 jurisdictions offering data for 96 elections.

Table 2 demonstrates that minorities have had success contesting these elections, despite low levels of representation prior to the change in election systems. A Latino candidate was elected in $70 \%$ of the contests where a Latino candidate sought office under CV. Further, in $96 \%$ of CV/LV elections where an AfricanAmerican sought office, at least one African-American was elected. Table 2 also illustrates something that will be discussed below: in elections where the predominant minority was Latino, Latino candidates were on the ballot in only $71 \%$ of elections.

Hypotheses about how elections translate minority voting age population share into minority seats on local councils can be tested by regressing seats against population (Engstrom and McDonald 1981). Bivariate regression produces slope estimates that can be used to assess differences in seats-population relationships across electoral systems, and can be compared to those produced by other studies using the same method. For example, when percentage data are used, a slope of 1.0 with an intercept of 0 indicates that minority seat shares on

TABLE 2

Racial/Ethnic Distribution of Cases

\begin{tabular}{lccr}
\hline $\begin{array}{l}\text { Predominant } \\
\text { Minority }\end{array}$ & $\begin{array}{c}\text { Total } \\
\text { Number of } \\
\text { Elections }\end{array}$ & $\begin{array}{c}\text { Elections with } \\
\text { Minority } \\
\text { Candidates }\end{array}$ & $\begin{array}{r}\text { Elections with } \\
\text { Minority } \\
\text { Victory }\end{array}$ \\
\hline Latino & 66 & $47(71 \%)^{\mathrm{a}}$ & $\begin{array}{r}33(50 \%)^{\mathrm{a}} \\
(70 \%)^{\mathrm{b}}\end{array}$ \\
African-American & 28 & $26(93 \%)^{\mathrm{a}}$ & $\begin{array}{r}25(89 \%)^{\mathrm{a}} \\
(96 \%)^{\mathrm{b}}\end{array}$ \\
Native American & 02 & $01(50 \%)^{\mathrm{a}}$ & $00(0 \%)^{\mathrm{ab}}$ \\
\hline
\end{tabular}

Note: Cases are individual elections. Data are from the two most recent elections, or the most recent election if the jurisdiction had only one CV/LV contest as of 1997.

apercent of all elections

${ }^{b}$ percent of elections where minority candidates sought office

\footnotetext{
${ }^{9}$ For example, if a place was electing five seats via CV (or LV) in an election, the dependent variable would be calculated as \# CV seats won by minority candidates/5. Likewise, if a place elected three seats via districts, and two via CV, the dependent variable would be \# CV seats won by minority candidates $/ 2$.
} 
local councils occur in exact proportion to the percent of the local voting age population that is minority.

Due to the nature of our data, our analysis is slightly different than some studies of minority representation. Many studies now use regression models estimated with a universe of medium and large cities (i.e., all cities over 50,000). With such data, a single model can be specified with multiple intercepts and interaction terms that represent how different electoral systems affect the seats-population relationship. Interaction terms allow single-equation models to test if various electoral structures have different effects on minority council representation (Bullock 1994; Bullock and MacManus 1993; Engstrom and McDonald 1981, 347; Welch 1990, 1055).

Our data differ from these "larger- $N$ " studies in that our cases are election results from smaller places and our sample is the universe of all known places above 1,000 population using CV or LV. Given the small number of cases, the unique characteristics of these communities, and the circumstances under which these election systems are adopted, we cannot include multiple intercept terms that directly compare the seats-population relationship under LV and CV to other systems.

Models are first estimated for all $\mathrm{CV}$ and LV jurisdictions, including cases where the predominant minority group is either African-American, Latino, or Native American ${ }^{10}$ (model 3.1). We then estimate separate models for AfricanAmerican and Latino places to assess if modified at-large voting is associated with a different seats-population relationship for these groups (models 3.2 and 3.3 , respectively). We also estimate a multivariate model with all cases using an interaction term and dummy variable to test if minority representation is more common under LV than CV (models 3.4). To evaluate our other hypotheses, the slopes resulting from these models are compared to those produced from other studies. This can provide some idea of how minority representation under modified at-large elections compares to other electoral systems used in U.S. localities.

Information about the slope of these relationships can be more important than a simple demonstration that more minorities serve on these local councils after changing to modified at-large voting. Each of these jurisdictions adopted new electoral systems because they had sizable minority populations with very limited (or in many places no) minority representation. Only two of these places have minority populations under $10 \%$ (the lowest being $7 \%$ ). ${ }^{11}$ In many (if not

\footnotetext{
${ }^{10}$ In a single $\mathrm{CV}$ jurisdiction (Sisseton, SD school district) the predominant minority group is Native American.

${ }^{11}$ For example, Thomas and Stewart $(1988,171)$ note that $44 \%$ of Alabama Black Belt counties examined in a 1982 federal study (U.S. Civil Rights Commission 1983, cited in Thomas and Stewart 1988) had no black representation. Many of these counties having no black representation had majority-black populations. A number of our towns are drawn from these counties. Each of the North Carolina places using LV were also in VRA targeted areas since 1964. Keech and Sistrom (1994) report that $90 \%$ of North Carolina counties and cities were unmodified at-large as of 1989 . Blacks were heavily underrepresented in these places. In places where blacks were a minority, representational equity scores did not exceed .20. Nearly all of our North Carolina cases come from these communities.
} 
most) of the jurisdictions included in our analysis, minority representation increased under modified at-large voting. Our models illustrate the systematic nature of this process in a manner that facilitates comparison with studies of other electoral systems.

\section{Results}

Results from model 3.1 indicate that when all modified at-large jurisdictions are examined simultaneously, there is a poor fit between minority population and percent of seats controlled by the minority groups. Variation in seats-population relationships across modified at-large places is evident when we examine African-American and Latino jurisdictions separately. The fit of the model is greatly improved $\left(R^{2}=.26\right)$ when African-American jurisdictions are examined in isolation $\left(R^{2}\right.$ increases to .45 when the analysis is restricted to cases with black candidates). Model 3.2 illustrates that for these places, the relationship between seats and minority voting age population is represented by a slope of .95 and an intercept not significantly different than zero. Thus, in those elections where the primary minority is African-American, as the minority percentage of the population increases, a nearly equivalent gain in descriptive representation is achieved. Furthermore, since the intercept is near zero, population share is translated into representation at low levels of minority population.

Model 3.3 reports the slope of the seats-population relationship for places where the predominant minority is Latino. Given the insignificant slope and the

TABLE 3

Minority Seats-Population Relationship under Cumulative and Limited Voting

\begin{tabular}{lcccc}
\hline & Model 3.1 & Model 3.2 & Model 3.3 & \multicolumn{2}{c}{ Model 3.4 } \\
\hline Variables & $($ All $)$ & $($ Black $)$ & (Latino) & $(\mathrm{LV})$ \\
\hline Minority \%VAP & .15 & $.95^{* * *}$ & .03 & .01 \\
LV Dummy & $(.18)$ & $(.31)$ & $(.21)$ & $(.18)$ \\
LV*Min\%VAP & - & - & -.19 & $(.15)$ \\
Intercept & - & - & .16 & $(.48)$ \\
$R^{2}$ & $.15^{* *}$ & .04 & $(.07)$ & $.17^{* *}$ \\
\hline Number of cases & $(.06)$ & $(.08)$ & .00 & $(.06)$ \\
\hline
\end{tabular}

Note: Dependent variable $=$ number $\mathrm{CV} / \mathrm{LV}$ council seats won by minorities divided by number of $\mathrm{CV} / \mathrm{LV}$ seats in election.

${ }^{\mathrm{a}} R^{2}$ for model 4 is adjusted; all others unadjusted.

$* * p<.05 ; * * * p<.01$ (two-tailed t-tests) 
very low $R^{2}$, there does not appear to be a substantive linear relationship between minority population share and minority seat share on councils and school boards. This does not mean that Latino candidates were not elected in places that adopted modified at-large voting. As with majority-African-American jurisdictions, Latino candidates were elected in greater numbers after switching to modified at-large. As reported in Table 2, where Latino candidates sought office, they were successful in over half (33 out of 47) of these cases-marking a dramatic improvement over previous levels of Latino representation in these communities (Brischetto 1995; Brischetto and Engstrom 1998). Nevertheless, elections in many places with substantial Latino populations produced no Latino representation due to both a lack of candidates or defeat at the polls. Even when the analysis is restricted to cases where Latino candidates sought office (not reported here), there is still no significant effect. In the discussion section we address how seats-population models can underestimate the potential for Latino representation.

We hypothesized that these new modified at-large systems would produce more-proportionate descriptive representation of minorities than standard atlarge plans, and less-proportionate representation than SMD plans. Our results are put into perspective by comparing the parameters from our models to those from other studies examining local election systems in the United States. If we compare our slope and intercept for African-American representation under modified at-large systems to those from previous studies of standard at-large systems, we find some support for these hypotheses.

As Figure 1 illustrates, the seats-population relationship for African-Americans under recently modified at-large voting is similar to that found by Welch (1990) for African-Americans in larger (over 50,000 residents) southern cities using SMD where blacks are a minority of the population. Figure 1 compares our results from model 3.2 to Welch's findings. Across much of the range in minority population, it appears modified (CV/LV) plans (represented by the dotted line) produce similar levels of representation as districting (the solid line), and slightly greater descriptive representation than standard at-large plans (the dashed line).

Since nearly all of our cases come from elections in relatively small places that recently switched election systems, Welch's data might not be best suited for comparing seats-population relationships across systems. When we compare our estimates to those from a study of other southern places that had recently switched away from AL plans - a study that includes many smaller, rural places more similar to communities in this study-levels of African-American representation under modified at-large plans appear more striking. Bullock (1994) examined elections to county commissions in Georgia in 1991. Of the counties studied, 52 used SMD plans, an increase from 17 in $1981 .{ }^{12}$ Figure 2 plots

\footnotetext{
${ }^{12}$ Like the cases in our study then, many of these places had recently moved away from AL plans in response to actual or potential VRA action under Section 2. As with our study, Bullock's cases were limited to places where African-Americans were in the minority $(N=149$ counties). Given the recent election system changes in many of these places, and the small population and rural nature of many, we suggest they are a good basis for making comparisons with our study.
} 
FIGURE 1

CV/LV Seats-Population Relationship Compared to Other Systems, U.S. South

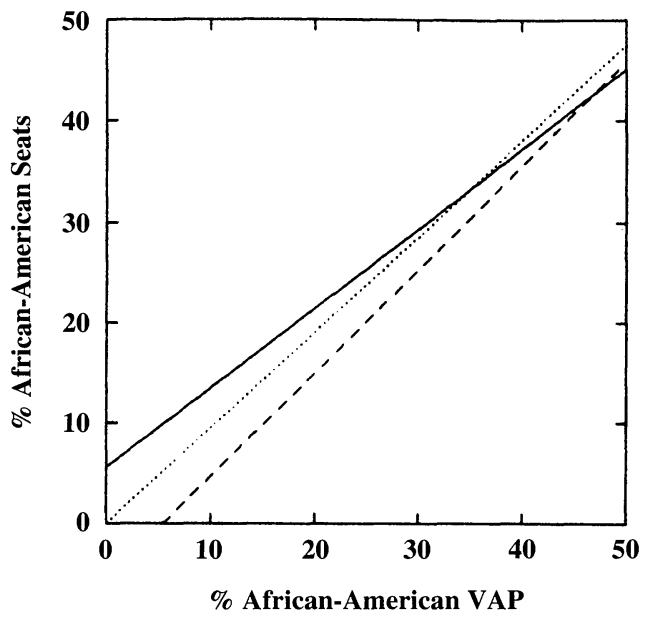

Solid $=$ Districted $($ Welch 1990)

Dashed $=$ At-Large (Welch 1990)

Dotted $=$ Modified At-Large (CV/LV)

FIGURE 2

CV/LV Seats-Population Relationship Compared to Other Systems, Small Southern Places

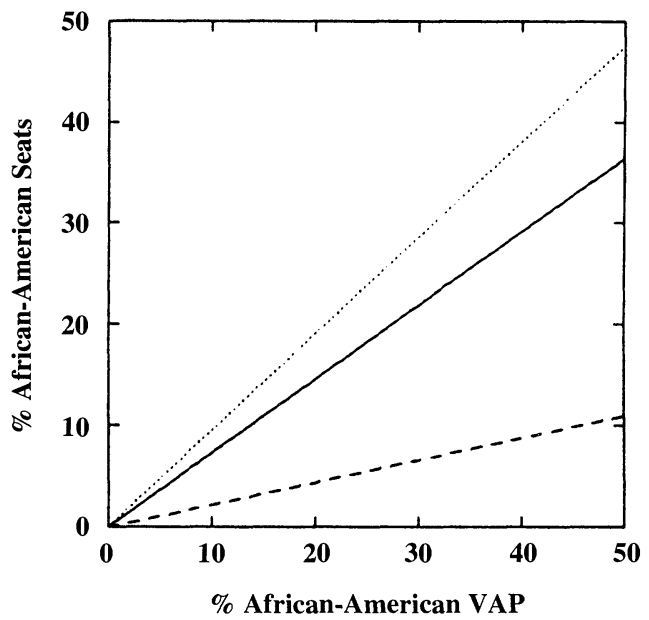

Solid $=$ Districted $($ Bullock 1994)

Dashed $=$ At-Large (Bullock 1994)

Dotted $=$ Modified At-Large $(\mathrm{CV} / \mathrm{LV})$ 
Bullock's bivariate seats-registration relationship in SMD places (the solid line) and the relationship we estimated in model 3.2 for African-American jurisdictions using $\mathrm{CV} / \mathrm{LV}$ plans (the dotted line). The plot demonstrates results contrary to one of our hypotheses-modified at-large elections actually produced slightly more proportionate outcomes when compared to these districted places.

The differences between standard at-large elections and CV/LV elections are substantial when we compare our estimates to those from Bullock's study of Georgia counties, and are consistent with the hypothesis that CV/LV plans will produce more-proportionate representation of minorities than traditional AL systems. The dashed line represents the bivariate seats-registration relationship for the 41 Georgia counties still using unmodified AL elections in 1991. Compared to these cases, modified at-large systems produced substantially greater descriptive representation for African-Americans. ${ }^{13}$

Our last hypothesis dealt with the difference between outcomes under LV versus CV systems. Since LV plans might involve fewer strategic burdens (e.g., vote dispersion coordination), we expected that LV systems could produce greater minority representation than CV. Model 3.4 included a coefficient reflecting the interaction between a dummy representing LV places and minority voting age population. In theory, this coefficient isolates the unique seats-population relationship for LV. The significant coefficient for the interaction term (1.12; $p<.05)$ can be seen as reflecting greater proportionate descriptive representation of minorities when comparing LV to CV places. This is consistent with assumptions that lower strategic demands are required for effective use of LV.

It is important to stress that there are relatively few cases of LV elections in the analysis in Table $3(N=17)$, and all are in places where the predominant minority is African-American. ${ }^{14}$ The interaction in model 3.4 could possibly capture the difference between African-American representation under LV and Latino and African-American representation under CV.

Another way to determine if minorities achieve higher representation under LV is to estimate the seats-population slope for the 28 places with AfricanAmerican minorities. We first estimate the seats-population slope unique to these places using CV (model 4.1), then compare this to the slope for AfricanAmerican places using LV (model 4.2). These results are reported in Table 4. Again, we find evidence suggesting a more-proportionate (or overproportionate) relationship between minority population and seats in LV elections $(b=1.12$,

\footnotetext{
${ }^{13}$ Differences between our estimates from CV/LV and Bullock's estimates from AL and SMD are even more striking. when we consider that our models use percent minority voting age population as the key independent variable, while Bullock uses percent minority voter registration. Given the gap between population and voter registration, our estimates could have been expected to be biased against finding proportionate relationships, which would be evident when registration data are used.

${ }^{14}$ All of the variation in election plans occurred across African-American places.
} 
TABLE 4

\section{African-American Seats-Population \\ Relationship under Cumulative and Limited Voting}

\begin{tabular}{lcc}
\hline & Model 4.1 & Model 4.2 \\
\hline Variables & (CV only) & (LV Only) \\
\hline Minority \%VAP & $.60^{* *}$ & $1.12^{*}$ \\
& $(.25)$ & $(.61)$ \\
Intercept & $.10^{* *}$ & -.02 \\
& $(.04)$ & $(.19)$ \\
$R^{2}$ & .38 & 19 \\
\hline
\end{tabular}

Note: Dependent variable $=$ number $\mathrm{CV} / \mathrm{LV}$ council seats won by minorities divided by number of $\mathrm{CV} / \mathrm{LV}$ seats in election.

${ }^{*} p<.10 ; * * p<.05$ (two-tailed t-tests)

$p=.08)$ than in $\mathrm{CV}$ elections $(\mathrm{b}=.60 ; p<.05) .{ }^{15}$ However, the population-seats coefficient under LV is not significantly larger than the coefficient under CV. The slope and intercept values for the population-seats model in Table 4 does suggest that $\mathrm{CV}$ communities elect black candidates at about the same rate as the districted places analyzed by Bullock as black populations approach $50 \%$. At lower ranges of black population, the intercept from model 4.1 indicates that $\mathrm{CV}$ produces greater representation than Bullock's SMD places.

There are many additional elements of election system variation that cannot be captured by these dummy variables (degree to which vote is limited, proportion of all seats elected CV or LV, years that jurisdiction has been using CV or $\mathrm{LV}$, etc.). Given limited degrees of freedom here, we cannot include these terms and thus cannot conclude with certainty that LV as practiced in the United States produces more-proportionate representation of minorities than $\mathrm{CV}$.

Finally, we should note that there are reasons to expect that the number of seats being contested should affect proportionality for any election system (Lijphart 1994). We did include this as an independent variable in preliminary models, but the effect was not significant. Since our goal is replicating models from other studies that did not include this measure, we do not include the term in models reported here. There is limited variance in number of seats contested among these elections, so it is difficult to evaluate the effect of this variable.

\footnotetext{
${ }^{15} \mathrm{~A}$ t-test of the difference between these slopes produces no significant difference. The power of the test is constrained by the small sample. When an interation term (LV*minority\%VAP) is included with all 28 cases from Table 4 , the coefficient is positive $(b=.52)$ but not significant.
} 


\section{Discussion}

Our data provide evidence that modifying local at-large elections with limited or cumulative voting offers the promise of minority representation at levels very similar to those found under SMD. This finding should be encouraging to those interested in facilitating minority representation without relying upon the acrimonious process of drawing districts on the basis of race. Previous research has established that minorities do win seats under these modified plans. Our purpose was to identify how the seats-population relationship under CV/LV compares to those produced under other plans. For African-Americans, representation from $\mathrm{CV} / \mathrm{LV}$ elections compares favorably to that obtained from SMD, and is more proportionate than representation under unmodified at-large. For Latinos in communities studied here, this might not be the case.

Our results from Latino places raise questions about why $\mathrm{CV}$ election outcomes are less than proportionate. In the cases examined here, underproportionality reflected by our estimates is likely related to a function of three main factors: (1) limited recruitment of Latino candidates, (2) a substantial gap between census measures of Latino voting age population (the key independent variable in these models) and actual rates of Latino participation in elections, and (3) the high threshold of exclusion built into CV plans adopted in many places where Latinos are the predominant minority.

Among our cases are a number of Texas CV elections $(N=33)$ having substantial Latino populations but achieving no Latino representation. In 19 of these cases, clerks indicated that no minority candidates filed for office. Likewise, there were only two cases where African-Americans comprised the predominant minority group and no African-American candidate sought office. Since the data reveal that the nomination problem is more substantial for Latino jurisdictions, undernomination can partially explain the lack of a linear relationship between seats and population share in majority-Latino jurisdictions.

There were also 14 cases where Latino candidates were defeated in places with significant Latino populations. A second major factor affecting our ability to estimate representation of Latinos in modified at-large systems was the use of census measures of voting age population. In most of the Latino places included in this analysis, Latino turnout was far lower than white turnout. ${ }^{16}$ Percent minority VAP data is likely to produce a lower estimated slope than would result had registration or turnout data been used, since these latter variables more accurately reflect minority electoral strength. The gap between census measures of voting age population and actual turnout rates is also likely to be smaller for African-Americans than for Latinos. When Latino turnout data were included in a model limited to the 14 Texas communities where such data are available and in which Latino candidates sought office in 1995, the slope for the Latino

\footnotetext{
${ }^{16}$ In two of these jurisdictions, minority turnout actually exceeded Anglo turnout and minority candidates were elected. Turnout data are reported in Brischetto and Engstrom 1998.
} 
seats-turnout relationship is $1.22\left(R^{2}=.30\right)$, and the result was statistically significant. ${ }^{17}$ This demonstrates that Latino candidates can do well under CV when Latino voters are mobilized.

Compounding the population-turnout gap is a third factor. Most places in Texas tended to have only two or three CV seats up in any single election. All but two of the Latino cases in the analysis came from Texas. This means that the threshold of exclusion is typically either $25 \%$ or $33 \%$ in Texas. Low minority turnout will be particularly problematic when this threshold is this high.

We should stress that none of these factors explaining lower rates of Latino representation are an automatic result of the use of modified at-large electoral system. Rather, the constraints lie in how some CV plans were designed, and how groups utilize the system. If no more than two seats are contested via $\mathrm{CV}$ in an election, it will be difficult for any minority to gain seats unless the minority votes as a block, controls a relatively large share of voting age population (near or greater than $33 \%$ ), and mobilizes voters to turn out at rates matching or exceeding the majority group's voters.

If, however, the election plan creates a threshold that does not exceed the minority group's electoral strength, and a minority political group is organized such that it can recruit candidates, perhaps have some control over nominations, and/or mobilize voters to direct all their votes to specific candidate(s), then many of the strategic burdens associated with $\mathrm{CV} / \mathrm{LV}$ can be overcome. Our results suggest that these burdens are clearly surmountable, and that CV/LV plans do facilitate proportionate descriptive representation of minority groups under easily obtainable conditions while avoiding the use of race-conscious districting. Our results suggest that many of the potential strategic burdens and coordination requirements associated with $\mathrm{CV}$ are readily overcome by minority candidates.

\section{Manuscript submitted 20 January 1997 \\ Final manuscript received 24 November 1997}

\section{References}

Amy, Douglas. 1993. Real Choices, New Voices. New York: Columbia University Press.

Brace, Kimball, Bernard Grofman, Lisa Handley, and Richard Niemi. 1988. "Minority Voting Equality: The 65 Percent Rule in Theory and Practice." Law and Policy 10(1): 43-62.

Brischetto, Robert. 1995. "The Rise of Cumulative Voting." Texas Observer; 28 July, 6.

Brischetto, Robert, and Richard Engstrom. 1998. "Cumulative Voting and Latino Representation: Exit Surveys in Fifteen Texas Communities.” Social Science Quarterly. Forthcoming.

$\rightarrow$ Bullock, Charles S. 1994. "Section 2 of the Voting Rights Act, Districting Formats, and the Election of African-Americans." Journal of Politics 56:1098-1105.

${ }^{17} 1995$ is the only year that turnout data by ethnic group are available for Texas places using CV. Latino candidates sought office in 15 Texas CV elections that year, and registration data were reported for 14 of these places. We are thus unable to prepare similar estimates using all 96 cases. These data are available in Brischetto and Engstrom 1998. 


\section{David Brockington, Todd Donovan, Shaun Bowler, and Robert Brischetto}

Bullock, Charles S. and Susan MacManus. 1993. "Testing the Assumptions of the Totality of Circumstances Test." American Politics Quarterly 21:290-306.

Christensen, Raymond, and Paul Johnson. 1995. "Toward a Context-Rich Analysis of Electoral Systems." American Journal of Political Science 39:575-98.

Cole, Richard, and Delbert Taebel. 1992. "Cumulative Voting in Local Elections: Lessons from the Alamagordo Experience.” Social Science Quarterly 73:194-201.

Cole, Richard, Delbert Taebel and Richard Engstrom. 1990 "Cumulative Voting in a Municipal Election: A Note on Voter Reactions and Electoral Consequences." Western Political Quarterly 43(4): 191-99.

Cox, Gary. 1991. "SNTV and d'Hondt are 'Equivalent." Electoral Studies 10(2): 118-32.

Cox, Gary. 1997. Making Votes Count. Cambridge: Cambridge University Press.

$\rightarrow$ Cox, Gary, and Emerson Niou. 1994. "Seats Bonuses under Single Non Transferable Vote Systems." Comparative Political Studies 26(2): 221-36.

Engstrom, Richard. 1993. "The Single-Transferable Vote: An Alternative Remedy for Minority Vote Dilution." Univerity of San Francisco Law Review 27(4): 781-813.

Engstrom, Richard, and Michael McDonald. 1981. "The Election of Blacks to City Councils: Clarifying the Impact of Electoral Arrangements on the Seats-population Relationship. American Political Science Review 75(2): 344-54.

Goldburg, Carol. 1994. "The Accuracy of Game Theory Predictions for Political Behavior: Cumulative Voting in Illinois Revisited.” Journal of Politics 56(4): 885-900.

Guinier, Lani. 1991. "No Two Seats: The Elusive Quest for Political Equality.” Virginia Law Review 77:1414-1514.

Guinier, Lani. 1994. Tyranny of the Majority: Fundamental Fairness in Representative Democracy. New York: Free Press.

Johnson, Richard. 1979. Political, Electoral, and Spatial Systems. Oxford: Oxford University Press.

Keech, William, and Michael Sistrom. 1994. "North Carolina." In Quiet Revolution in the South: The Impact of the Voting Rights Act, ed. Chandler Davidson and Bernard Grofman. Princeton: Princeton University Press.

Lakeman, Enid. 1970. How Democracies Vote. London: Faber and Faber.

Lijphart, Arend. 1994. Electoral Systems and Party Systems. New York: Oxford University Press.

Massey, Douglas, and Nancy Denton. 1987. "Trends in Residential Segregation of Blacks, Hispanics, and Asians: 1970-80." American Sociological Review 52(6): 802-25.

Pildes, Richard, and Kristen Donoghue. 1995. "Cumulative Voting in the United States." University of Chicago Legal Forum, 241-312.

Polinard, Jerry, Robert Wrinkle, and Tomas Longoria. 1991. "The Impact of District Elections on the Mexican American Community: The Electoral Perspective." Social Science Quarterly 72(3): 608-14.

Sass, Tim R., and Stephen Mehay. N.d. "Minority Representation, Election Method, and Policy Influence." Department of Economics, Florida State University. Unpublished manuscript.

Silva, Ruth. 1964. "Relation of Representation and the Party System to the Number of Seats Apportioned to a Legislative District." Western Political Quarterly 17(3): 742-69.

Still, Edward. 1984. "Alternatives to Single-Member Districts." In Minority Vote Dilution, ed. Chandler Davidson. Washington, DC: Howard University Press.

Still, Edward. 1991. "Voluntary Constituencies: Modified At-Large Voting as a Remedy for Minority Vote Dilution in Judicial Elections." Yale Law and Policy Review 9(2): 354-69.

Swain, Carol. 1993. Black Faces, Black Interests: The Representation of African-Americans in Congress. Cambridge: Harvard University Press.

Taagepera, Rein, and Matthew Shugart. 1989. Seats and Votes. New Haven: Yale University Press.

Taebel, Delbert. 1978. "Minority Representation on City Councils: The Impact of Structure on Blacks and Hispanics.” Social Science Quarterly 59(1): 142-52.

Thomas, James, and William Stewart. 1988. Alabama Government and Politics. Lincoln: University of Nebraska Press. 
Vedlitz, Arnold, and Charles Johnson. 1982. "Community Segregation, Electoral Structure, and Minority Representation." Social Science Quarterly 63(4): 729-36.

Welch, Susan. 1990. "The Impact of At-Large Elections on the Representation of Blacks and Hispanics." Journal of Politics 52(4): 1050-76.

David Brockington is Ph.D candidate in the Department of Political Science, University of Washington, Seattle, WA 98195.

Todd Donovan is associate professor of political science, Western Washington University, Bellingham, WA 98225.

Shaun Bowler is associate professor of political science, University of California, Riverside, Riverside, CA 92502.

Robert Brischetto is adjunct professor of sociology, University of Texas at San Antonio, San Antonio, TX 78285. 